"Were tobacco warehouse receipts an economic form of money during part of the Colonial period in Virginia?"

\begin{tabular}{ll} 
AUTHORS & Paul F. Gentle \\
\hline ARTICLE INFO & $\begin{array}{l}\text { Paul F. Gentle (2018). Were tobacco warehouse receipts an economic form of } \\
\text { money during part of the Colonial period in Virginia?. Public and Municipal } \\
\text { Finance, } 7(3), 37-42 . \text { doi:10.21511/pmf.07(3).2018.04 }\end{array}$ \\
\hline DOI & http://dx.doi.org/10.21511/pmf.07(3).2018.04 \\
\hline RELEASED ON & Friday, 21 December 2018 \\
\hline RECEIVED ON & Tuesday, 10 July 2018 \\
\hline ACCEPTED ON & Tuesday, 18 September 2018 \\
\hline LICENSE & (cc) EY \\
\hline This work is licensed under a Creative Commons Attribution 4.0 International \\
\hline License \\
\hline ISSN PRINT & "Public and Municipal Finance" \\
\hline ISSN ONLINE & $2222-1867$ \\
\hline PUBLISHER & $2222-1875$ \\
\hline FOUNDER & LLC “Consulting Publishing Company "Business Perspectives" \\
\hline
\end{tabular}

NUMBER OF REFERENCES

28

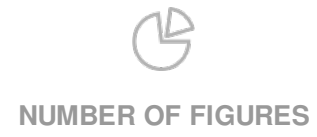

0
NUMBER OF TABLES

1

(C) The author(s) 2022. This publication is an open access article. 


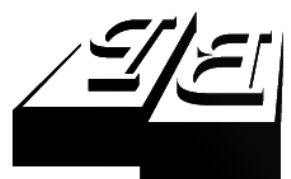

BUSINESS PERSPECTIVES

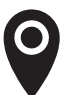

LLC "CPC "Business Perspectives" Hryhorii Skovoroda lane, 10, Sumy, 40022, Ukraine

www.businessperspectives.org
Received on: $10^{\text {th }}$ of July, 2018 Accepted on: $18^{\text {th }}$ of September, 2018

\footnotetext{
() Limited Liability Company "Consulting Publishing Company "Business Perspectives", 2018
}

Paul F. Gentle, Visiting Associate Professor of Business and Economics, NCC British Higher Education GZIT, Guangzhou, China.

\section{WERE TOBACCO WAREHOUSE RECEIPTS AN ECONOMIC FORM OF MONEY DURING PART OF THE COLONIAL PERIOD IN VIRGINIA?}

\begin{abstract}
This article examines the special use of tobacco warehouse receipts as a store of value, medium of exchange and unit of account in Virginia during part of the British Colonial period. These receipts met the three criteria necessary for them to be a type of money. When confidence in a system of currency with coins is present, this more conventional form of money takes precedence. A respected economic form of currency with coins has all three elements of money: medium of exchange, store of value and unit of account. Tobacco warehouse receipts were used as a form of money in Colonial Virginia. They were used since there was insufficient gold or silver for the commerce in British Colonial Virginia at that time. Also, the concept of store of value is examined in detail.
\end{abstract}

Keywords

JEL Classification defining money, commodity money, British Colonial period in Virginia, tobacco, gold, silver

\section{INTRODUCTION}

\section{Defining money and examples}

In this article, an answer is sought to determine if tobacco warehouse receipts served well as a form of money in British Colonial Virginia. Actually, money can be referred to "as anything that is generally accepted in payment for goods or services or in the repayment of debts" (Mishkin, 2006). At times, money is paper and coins and this is what lays people first think of when they hear the word money.

According to Mishkin (2006), in order for something to be money, three requirements must be met. These three requirements are being a store of value, a unit of account and a medium of exchange. There are special situations when something less familiar takes on traits of money, most often in an environment and time when currency with coins and other types of exchange are not present. For example, cigarettes were used as a type of money by prisoners of war camps in Germany during World War II (Radford, 1945). Prior to that, Native American wampum served as a means of recording treaties, histories, and sometimes messages within tribes and between tribes. Yet, once European settlers came to America, the wampum started also being used as money, becoming a medium of exchange, in parts of Eastern North America. Black beads of wampum were more valuable than white beads and so we can see an example of money with a unit of account (Gentle, 2016). 
An accepted currency with coin system would satisfy the three traits requirements well. Precious metals such as coins of gold and silver or notes, representing those precious metals, can also satisfy the necessary traits for something being money. The absence of sufficient and satisfactory currency with coins caused some alternatives to be used until currency with coin could be made available. In the case of prisoners of war in World War II, people used cigarettes as a medium of exchange within the German prisoner-of-war (POW) camps. And the unit of account requirement was satisfied well provided that there were still enough smokers within the POW camp economy. The store of value requirement would be at least somewhat satisfied (Radford, 1945). In the case of North American wampum, all three traits were satisfied. In part of Eastern North America, once Western European settlers came to the area until sometime in the eighteenth century, wampum was accepted as a medium of exchange, had units of account (black beads and white beads) and some store of value (Gentle, 2016). In the example of famous paintings used by Jews and German fascists as a medium of exchange amongst a limited number of people, the paintings did have a high store of value. Unfortunately, the famous paintings did not satisfy the unit of account requirement, since an artwork is not divisible. Paintings were worth very high values and the medium of exchange requirement is not met, as only a small number of people were involved in this. So, the relationships between different people of a certain wealth class and situation, such as Nazis being on the run, would account for some of the value of these paintings, as they could thus be sold or traded more easily, but only amongst a very small number of people. Therefore, the medium of exchange requirement for being money was not met by the valuable paintings (Gentle, 2017).

Anthropologists such as Herskovits (1965) express their concern about the relationships of people. Herkovits (1965) states that economists are primarily concerned with the material welfare of people. He maintains that anthropologists take this into consideration; however, it is viewed more in the context of how people relate to each other (Herskovits, 1965). Gentle $(2016 ; 2017)$ states that both economics and anthropology can simultaneously add to many discussions of social science topics.

\section{Virginia tobacco}

The research question addressed in this article is how well did the use of tobacco receipts in British Colonial Virginia serve as money. Then other forms of money are not available or do not inspire sufficient confidence, then people may have confidence in certain commodities to serve as a type of money (Rothbard, 2002). For instance, during part of the history of Colonial Virginia, warehouse receipts for tobacco were used between people as a form of money, since receipts were backed up by 100 percent tobacco (Brock, 1975; Rothbard, 2002). A comparable example would be rice in Colonial South Carolina (Rothbard, 2002). An examination of all the British colonies in North America is certainly intriguing. Yet, the focus of this article is on the use of tobacco receipts as a form of money in the Colony of Virginia.

\section{THEORETICAL BASIS}

\subsection{Value through tobacco commodity money in the Colony of Virginia}

\subsubsection{Subjective value}

The subjective value would be determined by the degree of an individual's pleasure or displeasure in looking at and owning an item (Subjective Value, 2016). In British colonies, a type of commodity money used in colonial times in Virginia was tobacco. Before using commodity money, the demand for tobacco was based on the utility that consumers obtained when using tobacco.

\subsubsection{Early history of tobacco cultivation in the Virginia Colony}

Herndon (1957) states, "Tobacco was probably first brought to the shores of England from Florida by Sir John Hawkins in 1565". And Sir Francis Drake was an important early importer of tobacco to England. John Rolfe eventually cultivated tobacco in Jamestown, Virginia, that was 
of the quality that England demanded. In regard to gold specie, there was not a large drain of that from England. In addition, England was able to accumulate some specie from those European countries that bought the Virginia-cultivated tobacco via England. In contrast, Virginia was paid for the tobacco with English manufactured goods (Herndon, 1957). By 1622, there were plantations as far as 140 miles up the James River; planters were strongly supporting tobacco cultivation (Herndon, 1957).

\subsubsection{Money considerations}

In the British colonies, there was of course some bartering going on. There were also very limited foreign coins and currencies, as well as colonial coins and currencies. But these were inadequate for the needs of the economies in different British colonies (Nettles, 1964; McCusker, 1978). And there was also the presence of commodity money (McCusker, 1978). Early on, sugar and tobacco were important in the West Indies and the colonies near the Chesapeake Bay (McCusker, 1978). "Fees, taxes, personal debts - all could be settled in pounds of these commodities" (McCusker, 1978). There was a diversity in locally produced crops and the resulting commodities could be used as a commodity and sometimes as money. The colonial governments sometimes determined the "legal value of sugar, tobacco, or whatever" (McCusker, 1978). Importantly, those commodities, markedly molasses and rum, tended to be used as commodity money, "without the benefit of law" (McCusker, 1978). Also, warehouse receipts for tobacco became tobacco notes and were circulated. Similar notes came from rum and molasses that would be distilled into rum (McCusker, 1978). Contiguous and to the North of Virginia is Maryland. During the colonial days of Maryland, tobacco served as one of its forms of commodity money from early on until 1812 (McCusker, 1978). The focus of this article remains on tobacco as commodity money and the Colony of Virginia. Warehouse receipts for stored tobacco served as a substitute for conventional money. Inspectors who were working in key places of Virginia insured the standardized quality of tobacco stored in warehouses (Pecquet, 2003). Interestingly, warehouses would act as banks that have 100 percent reserves for their circulating notes, the warehouse receipts (Pecquet, 2003). Large barrels were often used to store tobacco in. Sometimes horses, wagons, waterways, and roads were used to transport those barrels and other containers of tobacco (Herndon, 1957). The tobacco industry had many facets of effects on the Colonial Virginia economy. More wagons and sailing ships were built and utilized (Pettigrew, 2011). A tobacco hogshead was a large wooden barrel, measuring 48 inches (1,219 millimeters) long and 30 inches (762 millimeters) in diameter. These barrels, when packed with tobacco, weighed about 1,000 pounds or approximately 500 kilograms (Armstrong, 2018).

Although tobacco warehouse receipts were valuable as a form of money, there was sometimes an inadequate amount of these tobacco receipts in very rural areas. This is because some rural areas were too far away from the tobacco warehouses, which backed up tobacco receipts (Bullock, 1969). Notes, which were receipts on tobacco stored in warehouses, provided a relatively good type of money during the Colonial period of Virginia (Brock, 1975). Interestingly, Pecquet (2003) notes that the demand for tobacco during the Colonial period in Virginia often exhibited an inelastic trait. Pecquet (2003) believes that this was at least partially due to the "royal tobacco monopoly". When there is inelastic price demand elasticity, large percentage changes in price result in smaller percentage changes in quantity demanded (Mankiw, 2015). In 1614, Virginia Colony exported 2,600 pounds of tobacco. Then, in 1618, the amount increased to 50,000 pounds and in 1622 to 200,000 pounds. Ironically, in these early years, the lucrative activity of tobacco cultivation sometimes resulted in insufficient attention to food production and overworked the labor involved in tobacco cultivation (Goodman, 2005).

\subsubsection{Gresham's Law in action}

With the truth that more than one type of money existed in the Colony of Virginia, at a time, we should naturally be concerned with Gresham's Law. This economic concept states that bad money drives out good (Nettles, 1964; Bernholz et al., 1992; Gresham's Law, 2018). Mundell (1998) provides a fairly good analysis of different views of 
Gresham's Law. The Misean Economics School has their own economists and they have their own expression. It is that overvalued money drives undervalued money from the economy (Mises, 2018). There are many different ways of stating Gresham's Law. Regardless of the various special views on Gresham's Law, this paper will use that of an American economic historian, David O. Whitten (1993). That is, bad money drives out good, the same statement in the second sentence of this paragraph, as the definition we will use in this paper. For instance, if gold is the most valued type of money and the population has some gold and some alternative form of money, that is, less valuable than gold, we would expect the population to use the less valuable money in everyday transactions. Trying not using gold in transactions and instead using the less valuable form of money, is what Gresham's Law predicts (Nettles, 1964). So, in the case of Virginia, tobacco would be used as a medium of exchange, instead of gold, when possible (Nettles, 1964). However, coins, not tobacco, were often legally required for land purchases. So, when that type of transaction occurred, the more valuable type of money was used (Nettles, 1964).

\section{RESULTS}

As Mishkin (2006) has stated, one of the required traits for something to be considered money is being a store of value. This paper has mentioned several items that served as money. One common trait for these type of money is being a store of value. Yet, some types of money will hold their value longer than other types. For instance, a cigarette may decompose in as little as three months (Answers, 2018). A cigarette may not last as long as tobacco in a warehouse or in a large barrel. So, tobacco stored is a whole different product compared to cigarettes. Therefore, stored tobacco fulfills the store of value requirement perhaps longer than cigarettes do. The amount of a commodity has an effect on the value of that commodity-based money (Nettles, 1964). Wampum was made of shell beads and was thus more durable than cigarettes or stored tobacco. This paper has also considered valuable paintings in Germany during the Third Reich period. These valuable art works hold their value. However, the necessary criteria for medium of exchange and unit of account traits are not met.

In Table 1, a summary is given for three types of items that may or may not be money in the economic sense. These three types of items possess the necessary traits that make the item a type of economic money during a time in history at a particular geographic place.

So, what about gold and silver. How well do they retain value? Compared to the four items considered in Table 1, gold and silver have held their value quite well (Abdullah, 2013). Although very select paintings hold their value, as a general rule, art work is not a comparatively good investment in monetary terms. It may have some intangible values, such as the utility, "psychic income" in owning a work of art (Ekelund et al., 2017).

Over time, the type of money that may best hold its value in many situations could be based upon gold and silver (Greenspan, 1996; Abdullah, 2013). Indeed, both gold and silver were used for a time as an important basis for money (World Gold Council, 2018; Silver Coins, 2018). A detailed explanation of this goes beyond the scope of this paper.

Table 1. Certain items' ability to fulfill Miskin's three requirements to be money

\begin{tabular}{l|c:c|c}
\hline \multicolumn{1}{c|}{ ITEM } & $\begin{array}{c}\text { VALUE REQUIREMENT } \\
\text { SATISFIED }^{\mathbf{a}}\end{array}$ & $\begin{array}{c}\text { UNIT OF ACCOUNT } \\
\text { REQUIREMENT SATISFIED }\end{array}$ & $\begin{array}{c}\text { MEDIUM OF EXCHANGE } \\
\text { REQUIREMENT SATISFIED }\end{array}$ \\
\hline Wampum & $\mathrm{X}$ & $\mathrm{X}$ & $\mathrm{X}$ \\
\hdashline Tobacco warehouse receipts & $\mathrm{X}$ & $\mathrm{X}$ & $\mathrm{X}$ \\
\hdashline $\begin{array}{l}\text { Cigarettes in POW camps } \\
\text { during World War II }\end{array}$ & $\mathrm{X}$ & $\mathrm{x}$ & $\mathrm{X}$ \\
\hline
\end{tabular}

Note: ${ }^{a}$ This may vary depending on the item. 


\section{DISCUSSIONS AND CONCLUSION}

When conventional forms of money are not ubiquitous at all, people may turn to substitutes such as wampum or tobacco. In this article, there has been a focus on the use of tobacco warehouse receipts during part of the Colonial period of Virginia. These receipts fulfilled the three requirements for something to be money. The receipts were widely circulated as a medium of exchange. The units of account are given by the amount and quality of tobacco that the receipt stood for. The receipts are a store of value, because they are backed up by a specific amount and quality of tobacco. After a time, national currency and coin came into being, many years later as the United States of America came into being. In regard to the fundamental question of this article, "Were tobacco warehouse receipts an economic form of money during part of the Colonial period in Virginia?", the answer would be yes.

As the economic history of a place progresses, one can expect the forms of money to sometimes change. So, it was with the place called Virginia. This state of Virginia is now part of the USA and is now linked in with that country's monetary system.

\section{REFERENCES}

1. Abdullah, A. (2013). Examining the Value of Money in America over the Long Term (1792-2009). International Journal of Economics and Finance, 5, 58-84. https://doi. org/10.5539/ijef.v5n10p58

2. Answers (2018). How long does a cigarette take to decompose? Retrieved from http://health.answers.com/Q/How_long_does_a_ cigarette_take_to_decompose

3. Armstrong, M. (2018). Paper chase. Retrieved from https://www.armstrongeconomics.com/research/abrief-history-of-paper-money/ the-paper-chase-part-i/

4. Bernholz, P., \& Hans, G. (1992). Gresham's Law: Theory. The New Pelgrave Dictionary of Money and Finance, 2, 286-288. London: McMillan.

5. Brock, L. V. (1975). The Currency of the American Colonies: 17001764: A Study in Colonial Finance and Imperial Relations. New York: Arno Press.

6. Bullock, Charles J. (1969). Essays on the Monetary History of the United States. New York: Greenwood Press.

7. Ekelund, R. B. Jr., Jackson, J. D., \& Tollison, R. D. (2017). The Economics of American Art: Issues, Artists and Market Institutions. Oxford University Press. https://doi.org/10.1093/ oso/9780190657895.001.0001
8. Gentle, Paul F. (2016). Native American Wampum for NonMonetary Uses and For Use as Money. Public and Municipal Finance, 3, 16-21.

9. Gentle, Paul F., \& Marco Gilibreti (2017, December). Were Valuable Art Works an Economic form of Money during the Third Reich period in Germany? Public and Municipal Finance, 33-38.

10. Goodman, J. (Ed.) (2005). Tobacco. In Tobacco in History and Culture: An Encyclopedia. New York: Scribner.

11. Greenspan, A. (1966). Gold and economic freedom. The Objectivist Newsletter. Retrieved from http:// www.321gold.com/fed/greenspan/1966.html

12. Gresham's Law (2018, April 21). In Wikipedia. Retrieved from https://en.wikipedia.org/wiki/ Gresham's_law

13. Herndon, G. M. (1957). Tobacco in Colonial Virginia: The Sovereign Remedy. Williamsburg, Virginia: Virginia $350^{\text {th }}$ Anniversary Celebration Corporation.

14. Herskovits, M. J. (1965). Economic Anthropology: The Economic Life of Primitive Peoples. New York: W. W. Norton, Incorporated.

15. Mankiw, N. Gr. (2015). Principles of Economics. Stamford, CT: Cenage Publishers.
16. McCusker, J. J. (1978). Money and Exchange in Europe and America, 1600-1775: A Handbook, Chapel Hill. North Carolina: University of North Carolina Press.

17. Mises Institute (2018). Gresham's Law. Retrieved from https://wiki. mises.org/wiki/Gresham\%27s_ Law

18. Mishkin, F. S. (2006). The Economics of Money, Banking, and Financial Markets. New York: Pearson Addison-Wesley.

19. Mundel, R. (1998). Uses and Abuses of Gresham's Law in the History of Money. Zagreb Journal of Economics, 2(2).

20. Nettles, A. M. (1964). The Money Supply of the American Colonies before 1720 (Reprint of 1934 edition). New York: Sentry Press.

21. Pecquet, G. M. (2003). British Mercantilism and Crop Controls in the Tobacco Colonies: A Study of Rent-Seeking Costs. Cato Journal, 22(3), 467-484. Retrieved from https://ideas.repec.org/a/cto/ journl/v22y2003i3p467-484.html

22. Pettigrew, W. A. (2011). Historizing Supply and Demand in Early American Economic History: The Importance of Transatlantic Policies. The William and Mary Quarterly, 68(3), 409413. https://doi.org/10.5309/willmaryquar.68.3.0409 
23. Radford, R. A. (1945, November). The Economic Organization of a P.O.W. Camp. Economica, 12(48), 189-201.

24. Rothbard, M. N. (2002). A History of Money and Banking in the United States: The Colonial Era to World War II. Auburrn, Alabama: Ludwig Von Mises Institute.
25. Silver Coins (2018). Silver as Money: A History of U.S. Silver Coins. Retrieved from http://www. silvercoins.com/history-of-silveras-money/

26. Subjective Value (2016, December 25). Subjective Theory of Value. Retrieved from https:// en.wikipedia.org/wiki/Subjective_theory_of_value
27. Whitten, D. O. (1993). Lecture, American economic history. Auburn University.

28. World Gold Council (2018). Money and Gold. Retrieved from https://www.gold.org/aboutgold/history-of-gold/moneyand-gold 